\title{
Lei do Abate, guerra às drogas e defesa nacional
}

\author{
Brazilian Shoot-Down Law (Lei do Abate), \\ War on Drugs and national defense
}

GUSTAVO RAPOSO PEREIRA FEITOSA*

JOSÉ AUGUSTO DE OLIVEIRA PINHEIRO**

Rev. Bras. Polit. Int. 55 (1): 66-92 [2012]

\section{Introdução}

O evento do abate de um avião Cessna com missionários norte-americanos em 2001 chamou atenção internacional para os programas de interdição aérea que autorizavam a derrubada de aeronaves civis em áreas do Peru e da Colômbia. Desde 1994, as operações destinadas a impedir o transporte aéreo associado ao tráfico ilícito de drogas nos dois países ocorriam com baixa ou nenhuma repercussão, não obstante o longo histórico de rejeição internacional ao uso de armas contra aeronaves civis (Huskisson 2005).

A compreensão sobre a introdução de políticas de controle do narcotráfico por intermédio da derrubada de avióes envolve uma difícil leitura sobre os modelos de combate às drogas, sobre as políticas dos EUA acerca do tema e sobre a posição dos países latino-americanos diante das ameaças reais ou potenciais na Região Amazônica.

O assunto ganha maior importância para o Brasil a partir de 1988, quando se modificou o Código Aeronáutico Brasileiro de modo a autorizar uso do tiro de destruição contra aeronaves civis em voo suspeitas de participar do tráfico ilícito de entorpecentes. A mudança ganhou o nome de Lei do Abate e acabou regulamentada apenas em 2004, após um lento processo de discussão e negociação envolvendo militares, as autoridades civis brasileiras e o governo norte-americano. A lei colocou o Brasil junto do Peru e da Colômbia no grupo dos países com programas semelhantes.

A grande novidade para o Brasil reside na possibilidade do uso letal da Força Aérea sem que haja necessariamente um ataque armado ou uma medida hostil

\footnotetext{
* Professor do Programa de Pós-Graduação em Direito Constitucional da Universidade de Fortaleza (Unifor) e professor da Faculdade de Direito da Universidade Federal do Ceará (UFC) (gfeitosa@terra.com.br).

** Advogado e Membro do Grupo de Pesquisa: Direito e Relações Internacionais, Segurança e Reforma do Estado da Universidade de Fortaleza (Unifor) (augusto.pinheiro@uol.com.br).
} 
caracterizadora de um ato de guerra. Essa opção remete aos tempos mais tensos da Guerra Fria, quando aviōes de passageiros se transformavam em alvos militares por violarem o espaço aéreo de outro país ou por erro na identificação de possíveis atos de espionagem.

A análise dos principais casos de abate de aeronaves civis registrados pelo mundo afora desde o fim da Segunda Guerra Mundial revela o forte consenso internacional acerca do repúdio ao uso de violência contra aviōes civis. Em nenhum dos casos, os Estados responsáveis pela derrubada pretenderam construir argumentos para legitimar os ataques. As respostas oficiais resumiam-se ao reconhecimento do erro ao interpretar uma violação territorial ou um ato hostil, ou ainda a tentar demonstrar que houve um erro justificável diante das circunstâncias (Huskisson 2005, 19-27).

O novo cenário internacional pós-Guerra Fria oferecia pouco espaço para a justificação de medidas de destruição contra aeronaves civis. Aparentemente, a década de 1990 representaria o início de uma nova etapa para o tratamento das violações de espaço aéreo, menos sujeita à hipótese de derrubada de aeronaves em tempo de paz. A criação de leis e políticas fundadas na possibilidade de destruir aviōes suspeitos de tráfico de drogas em pleno voo num contexto anterior aos atentados de 11 de setembro de 2001 e em áreas amazônicas de três países da América Latina foge das características dos eventos de abate encontrados em diversas ocasióes do século 20 .

O presente estudo pretende analisar os antecedentes da criação dos programas de interdição aérea na América Latina, o processo de discussão, criação e regulamentação da Lei do Abate no Brasil e suas relações com os projetos militares para a regiāo amazônica. O trabalho divide-se em duas partes: na primeira, analisam-se as origens do modelo de guerra às drogas norte-americano e a evolução das políticas antidrogas dos EUA nas últimas décadas, tendo em vista sua ligação com a criação das leis de abate na Colômbia e no Peru; na segunda parte, aborda-se o processo de discussão interna no Brasil sobre a criação e aplicação da Lei do Abate e suas eventuais ligações com as políticas de defesa nacional e de combate ao crime.

\section{Guerra às drogas e Lei do Abate}

A discussão sobre a importância da Lei do Abate liga-se umbilicalmente às políticas norte-americanas de combate às drogas. Desde a década de 1970, a repressão à produção e distribuição de entorpecentes pelos EUA orienta-se segundo as premissas da chamada guerra às drogas, cuja forma variou ao longo das últimas décadas, mas repousa sobre os mesmos postulados: controle da entrada das drogas nos EUA, com o endurecimento da repressão contra o tráfico, de modo a reduzir a oferta do produto, e a criação de mecanismos para desestimular o uso de entorpecente, como a prisão dos usuários, a fim de tentar reduzir a demanda. 
A ênfase das políticas oscilou entre duas vertentes: a) maior controle interno sobre a venda de drogas nas ruas, sobre os usuários e sobre as fronteiras nacionais; b) repressão da produção, transporte e distribuição em outros países, associada ao combate às grandes organizaçôes criminosas (Bertram et al. 1996, 6). O maior ou menor relevo dado à redução da oferta ou da demanda interferiu diretamente nas políticas dos EUA para o combate às drogas. A aparente simplicidade dos dois lados dessa equação econômica (oferta e demanda) esconde, todavia, um grande conjunto de condicionantes associados às questôes de defesa nacional, ao combate ao crime, à política externa, à Guerra Fria, à ordem internacional e ao próprio modelo liberal de justiça e proteção constitucional de direitos.

A origem da chamada guerra às drogas (War on Drugs) remonta à disputa eleitoral para a presidência dos EUA em 1968. A campanha de Richard Nixon centrou-se na importância de restaurar a "lei e a ordem" (law and order) no país, com um discurso fundamentado na retórica do combate ao crime nas cidades, não obstante o fato de o governo federal americano não possuir atribuição de atuar no controle da criminalidade urbana. Apenas alguns crimes, como aqueles de natureza interestadual, internacional ou crimes do colarinho branco poderiam sofrer repressão das forças federais (Baum 1996, 14-17).

Para superar tal obstáculo, Nixon iniciou seu trabalho com mudanças legislativas dirigidas para o Distrito de Columbia, área urbana sob direta administração federal. Mesmo com baixas taxas de homicídios, a região sofria com altos índices de roubos e furtos, causando uma impressão de descontrole. Optou-se por criar mecanismos mais duros de ação, facilitando as buscas domiciliares, endurecendo as penas e ampliando as possibilidades de vigilância. $\mathrm{O}$ uso de drogas foi tratado como principal causador da crescente criminalidade, merecendo, assim, tratamento especial ${ }^{1}$. As propostas passaram facilmente no Congresso, na medida em que os democratas reagiram à derrota eleitoral tentando se apropriar do discurso da lei e da ordem $\mathrm{O}$ combate às drogas surgiu como uma alternativa legal, dentro do modelo federativo norte-americano para justificar a intervenção sobre assuntos estritamente locais (Baum 1996, 15-17).

Ao longo do governo Nixon, as medidas repressivas contra as drogas fortaleceram-se e o tema fixou-se na agenda política norte-americana como um problema de grande relevo. Nesse cenário, a divulgação de evidências da grande extensão do vício da heroína entre os militares americanos no Vietnam obrigou Nixon a intensificar ainda mais suas ações antidrogas. Em 1973, autorizou-se

\footnotetext{
1 Em discurso proferido em 31 de janeiro de 1969, Nixon destacou suas propostas para o Distrito de Columbia. Nessa manifestação pública encontram-se as linhas fundamentais do discurso da lei e da ordem que dominarão permanentemente o debate sobre a segurança pública nos EUA e se manterá presente de maneira sempre crescente em todo o mundo até os dias de hoje. Propostas como penas mais duras, redução nas restrições à ação policial e repressão ao tráfico de drogas surgem na fala de Nixon como um modelo federal destinado a inspirar as políticas de segurança pública em todos o país. Um dos pressupostos das novas concepções que se manteria como legado da administração Nixon consistia na ideia de que o tráfico e o consumo de drogas representam uma das principais causas do aumento da criminalidade (Nixon 1969a; Nixon 1969b).
} 
a criação da Drug Enforcement Administration (DEA), que deveria combinar os diversos agentes federais envolvidos no combate às drogas. Não obstante o legado como pai da guerra às drogas, a administração Nixon aplicou mais recursos em tratamento e redução da demanda do que em repressão à entrada de entorpecentes no país (Carpenter 2003, 11-16).

O sucesso eleitoral do discurso da lei e da ordem de Nixon demarcou um novo campo do debate eleitoral para fora do qual os partidos e candidatos não poderiam mais fugir. Sobre as premissas das propostas e das políticas de Nixon nenhum presidente ou candidato conseguiu romper efetivamente com a crença na necessidade de leis mais duras, mais repressão e mais empenho no combate ao crime, especialmente ao tráfico de drogas.

Durante as administrações Gerald Ford e Jimmy Carter, a mudança no discurso da lei e da ordem e da repressão ao tráfico não significou alteração nos rumos das açóes repressivas e punitivas. As variaçóes na retórica e a aparente liberalidade escondiam a preservação dos pressupostos das políticas lançadas na Era Nixon (Carpenter 2003, 15-16).

O retorno dos republicanos à Casa Branca amparados em plataformas mais conservadoras acarretou apenas a intensificação da estratégia de guerra e uma mudança na postura pública dos presidentes quanto aos temas associados ao consumo e ao tráfico. Coube a Ronald Reagan e a George H. W. Bush a tarefa de repercutir e dar nova dimensão ao que seriam os efeitos daninhos da "degradação moral" ocorrida nos anos de 1960 e 1970 (Bertram et al. 1996, 6). O conteúdo moral conservador do período Nixon ganhou novo destaque e refletiu seriamente na abordagem da política antidrogas nos anos de 1980 e 1990.

Iniciou-se um período de transição na forma de interpretação sobre os efeitos do narcotráfico e suas relações com as questôes de segurança nacional nos EUA. $\mathrm{Na}$ análise estratégica sobre os riscos dos movimentos revolucionários de esquerda na região, o narcotráfico ampliou seu status como agente financiador das atividades de guerrilha e uma das mais importantes ameaças à segurança do hemisfério sul. Desde 1980, o narcotráfico vinha se destacando como uma "ameaça proeminente", ao mesmo tempo em que os EUA identificavam ameaças terroristas em praticamente todos os países latino-americanos (Weeks 2006, 62; Rodrigues 2002, 105).

$\mathrm{O}$ combate à ameaça comunista internacional não prescindia do empenho norte-americano no ataque ao já considerado narcoterrorismo. Revela-se uma mudança importante no discurso em defesa da presença dos EUA na América do Sul, deslocando-se gradualmente dos temores da influência soviética para a necessidade de oferecer suporte ou mesmo intervir diretamente para conter o avanço da "ameaça do tráfico internacional de entorpecentes" (Rodrigues 2002, 105-106).

Toda a administração Reagan foi marcada pela nova ênfase no combate ao terrorismo como aspecto central da estratégia de segurança nacional. A construção dos contornos dessa nova ameaça reforçaria a concepção do terrorismo como problema global, associado, entre outros fatores, ao apoio de Estados estrangeiros, 
merecendo, segundo a leitura norte-americana, atenção redobrada de todas as naçōes ${ }^{2}$. Em 1984, lançou-se a diretiva presidencial para segurança nacional no 138 (NSDD138) contemplando um pacote de leis destinado a combater os ataques às aeronaves civis, evitar e reprimir o sequestro e uso de reféns, recompensar informações sobre terroristas e proibir treinamento e suporte às organizações terroristas. Nesse ambiente, nasceu o Aircraft Sabotage Act, lei diretamente aplicável às situações de derrubada de aeronaves civis.

Por trás da mudança, esconde-se um esforço para redefinir as prioridades da segurança nacional dos EUA num contexto de fim da Guerra Fria e de crescente crítica aos orçamentos militares. A legitimidade das demandas por manutenção de efetivos e de gastos dependia da capacidade de identificar um novo inimigo que exigisse constante e intensa atenção. O Pentágono, tradicionalmente, resistia ao emprego de militares em atividades típicas de combate ao crime ${ }^{3}$; contudo, vislumbrou na ação internacional antidrogas uma possibilidade de preservar parcelas do orçamento para a defesa (Schnaubelt 1994).

A estratégia nacional antidrogas passou a centrar-se definitivamente na interdição da entrada de entorpecentes nos EUA por meio da ação conjunta de diversas agências governamentais, com o suporte do Departamento de Defesa. Contudo, o crescimento do papel militar nas ações antidrogas exigiu a mudança no Posse Comitatus Act de 1878, que vedava a participação de forças militares norte-americanas em atividades típicas de polícia. Em 1981, o Congresso dos EUA tornou mais flexível e clara a autorização para a atuação das Forças Armadas no suporte ${ }^{4}$ de operaçōes antidrogas dentro e fora dos EUA (Beaty 1996, 1-2; Schnaubelt 1994) A mudança guarda coerência com o modelo de guerra às drogas e com a definição do tráfico como um problema de segurança nacional.

2 De maneira explícita o documento relata que: "National Security Decision Directive (NSDD) 138. [...] Terrorism is a problem for all nations, and this Government will work as closely as possible with other governments - particularly other similarly threatened democracies - to deal with it." (USA, 1984)

3 O Congresso dos EUA, no fim dos anos de 1980, lançou um apelo para uma maior intervenção dos militares na "guerra às drogas". A ideia não era nova, pois os militares norte-americanos atuavam na formação e no transporte de pessoal antinarcóticos desde 1983, além de participar, periodicamente, de ataques militares multilaterais contra operações de tráfico fora das fronteiras dos EUA. Apesar da óbvia capacidade militar de oferecer suporte às ações antidrogas, permanece a dúvida sobre a eficácia da ampliação do seu papel nesse tipo de atividade. Por um lado, há a definição do tráfico de drogas como um problema de segurança nacional para os EUA e a convicção de que somente as Forças Armadas encontram-se equipadas adequadamente para combater as organizaçóes criminosas de traficantes. De outro lado, alega-se que o combate ao tráfico de drogas não integra a missão dos militares, que os traficantes utilizam táticas de guerra não convencional para a qual as forças armadas estão mal preparadas, que há uma exposição desnecessária ao risco da corrupção, entre outros fatores (Perl 2006, 10-11; Perl 1997).

4 A limitação básica à atuação do Departamento de Defesa dos EUA nas ações contra o tráfico de drogas consiste na vedação à atuação direta em operaçōes de combate ao crime, como buscas, apreensōes e prisões. Prevalece a ideia de suporte, ou seja, a possibilidade de oferecer a infraestrutura e as competências militares para auxiliar a ação policial, como transporte, treinamento, equipamento, planejamento etc. Para que ocorra esse suporte em países estrangeiros, os militares respondem a um pedido formal do país encaminhado pela embaixada dos EUA (Schnaubelt, 1994). 
A chegada ao poder de George H. W. Bush em 1989 elevou ainda mais o status atribuído ao tráfico de drogas como problema de segurança nacional's O lançamento em cadeia nacional de uma estratégia nacional antidrogas em setembro de 1989 demonstra a importância do tema para o governo Bush ${ }^{6}$. Nesse plano, previa-se um grande número de medidas domésticas associadas ao tratamento e à prevenção, mas mantinha o foco na redução da oferta (Beaty 1996, 4). Em mais um momento, repercutia nas políticas externa e de defesa a temática da lei e da ordem explorada na campanha eleitoral. No mesmo discurso eleitoral, Bush misturava referências à decadência moral, às dificuldades internas dos EUA e às necessidades de segurança e de atuação internacional.

A estratégia incluía suporte econômico aos principais países produtores de cocaína, a concentração no desmantelamento das grandes organizações criminosas responsáveis pelo tráfico, encorajamento da participação militar no combate ao narcotráfico em países andinos, a oferta de colaboração militar norte-americana para o suporte de açóes antidrogas dos países produtores e distribuidores, e concentração das ações contra lideranças do tráfico, entre outras medidas. A mais importante parte do plano para a América Latina consistia na Andean Initiative, que previa a aplicação de US $\$ 5,5$ bilhôes em cinco anos para combater as grandes organizações criminosas ligadas ao tráfico no Peru, na Colômbia e na Bolívia (Perl 1997; Bush 1989).

O Departamento de Defesa norte-americano passou, desde então, a desempenhar um papel central para a realização das políticas antidrogas. A concentração da estratégia de 1989 na redução da oferta de drogas dentro do território norte-americano exigia o envolvimento amplo dos militares nas operaçôes de interdição destinadas a limitar o fluxo de entorpecentes pelas fronteiras nacionais. Iniciou-se, então, a verdadeira guerra às drogas e o consequente aprofundamento do combate ao tráfico internacional como parte das tarefas de defesa nacional realizadas pelas forças armadas americanas.

Durante os primeiros anos de aplicação das novas políticas antidrogas de Ronald Reagan e George H. W. Bush, prevaleceu o esforço de redução da oferta baseado na atuação sobre os países de trânsito e na tentativa de controle da passagem das drogas pela fronteira. Essa interdição envolveu o aprimoramento

5 Com a criação em 1988 do White House Office of National Drug Control Policy (ONDCP) por meio do Anti-Drug Abuse Act, iniciou-se a sistemática do lançamento anual da estratégia nacional antidrogas. A principal tarefa do ONDPC consiste em estabelecer políticas e prioridade nacionais para o controle e o combate às drogas.

6 Em parte de seu discurso, o presidente ressalta: "This is the first time since taking the oath of office that I felt an issue was so important, so threatening, that it warranted talking directly with you, the American people. All of us agree that the gravest domestic threat facing our nation today is drugs. [...] Finally, I want to thank President and Mrs. Reagan for their leadership. All of these good people told the truth-that drug use is wrong and dangerous. Frequent use of cocaine soars. [...] Our weapons in this strategy are: the law and criminal justice system; our foreign policy; our treatment systems, and our schools and drug prevention programs. [...] The war on drugs will be hard-won, neighborhood by neighborhood, block by block, child by child. If we fight this war as a divided nation, then the war is lost. But, if we face this evil as a nation united, this will be nothing but a handful of useless chemicals." 
dos mecanismos militares de monitoramento e rastreamento de aeronaves e embarcaçôes suspeitas de envolvimento no tráfico. Os sofisticados e relativamente eficientes instrumentos de controle obrigaram a uma constante transformação nas formas de transporte utilizadas pelos traficantes, como a ocultação em meio a mercadorias lícitas em navios, tornando pouco eficaz a política de interdição (Beaty 1996, 2-4; Peceny e Durnan 2006; Schnaubelt 1994).

Em 1995, durante a presidência de Bill Clinton, uma nova estratégia foi lançada ${ }^{7}$, alterando o foco das regiōes de trânsito para os países produtores (USA 1995a, 11). Avançava-se ainda mais longe a frente de combate para tentar conter a oferta de droga por intermédio de ações mais diretas sobre a produção e sobre as primeiras etapas da distribuição. A alteração do foco de ação seguia a diretiva presidencial $\mathrm{n}^{\circ} 14$, publicada em 1993 , como resultado da revisão das políticas e estratégias internacionais dos $\mathrm{EUA}^{8}$.

Desde a introdução da ideia de guerra às drogas na administração Nixon, a avaliação do sucesso das políticas antidrogas prendia-se à capacidade de diminuir o fluxo de entorpecentes através das fronteiras. A intensificação dessas medidas de interdição nas décadas seguintes exigia o controle do espaço aéreo e o monitoramento do uso de pequenos aviōes pelos traficantes. A crescente importância das políticas antidrogas norte-americanas em países produtores levou, assim, ao desenvolvimento de programas destinados a conter a rede aérea de transporte do tráfico fora das fronteiras nacionais.

Os primeiros passos dessas iniciativas ocorreram no começo dos anos 1990, quando as forças armadas norte-americanas iniciaram uma série de açôes que incluía um programa de monitoramento da "ponte-aérea" do tráfico chamado Support Justice. As informações coletadas serviram para o Peru iniciar um programa de interdição aérea, originalmente sem a necessidade de usar a força contra as aeronaves dos traficantes (Huskisson 2005, 112; Guáqueta 2005, 39). O compartilhamento de informações de monitoramento aéreo em tempo real oferecia, contudo, condições técnicas para as operações de abate.

Por trás de todo esse esforço para incrementar a participação do Departamento de Defesa nos países produtores de cocaína, como Peru e Colômbia, encontravase a necessidade objetiva de oferecer suporte na luta contra a guerrilha. $\mathrm{O}$ longo

7 A estratégia de segurança nacional (A National Security Strategy Of Engagement And Enlargement) lançada em 1995 por Bill Clinton estabelecia: "The U.S. has shifted its strategy from the past emphasis on transit interdiction to a more evenly balanced effort with source countries to build institutions, destroy trafficking organizations and stop supplies. We will support and strengthen democratic institutions abroad, denying narcotics traffickers a fragile political infrastructure in which to operate. We will also cooperate with governments that demonstrate the political will to confront the narcotics threat." (USA 1995a, 11)

8 A diretiva presidencial estabelecia: "[...] The President's directive, the result of an exhaustive eight-month review of U.S. international policies and strategies, instructed Federal agencies to change the emphasis in U.S. international drug programs from the past concentration largely on stopping narcotics shipments to a more evenly distributed effort across three programs: [...] emphasizing more selective and flexible interdiction programs near the U.S. border, in the transit zone, and in source countries" (USA, 1993). 
conflito armado vivido pelos dois países e o risco sempre presente de expansão das atividades da guerrilha para outras naçôes latino-americanas, especialmente na Região Amazônica, justificavam uma análise sobre o papel estratégico desses países na contenção da ameaça desses movimentos.

Ao mesmo tempo, o sucesso relativo na desarticulação dos cartéis de traficantes tornava a associação entre o narcotráfico e os grupos guerrilheiros uma alternativa necessária para o funcionamento da rede de produção de cocaína em áreas submetidas ao controle da guerrilha. A articulação entre o narcotráfico ampliava as fontes de financiamento para guerrilha e suas possibilidades de atuação no confronto com o exército, ao mesmo tempo em que oferecia novos arranjos para a produção e transporte de cocaína (Peceny e Durnan 2006). A mudança pôde ser percebida na inclusão dos grupos guerrilheiros na lista de organizaçôes consideradas terroristas pelo governo dos EUA e no tratamento do conflito com a guerrilha e o combate ao narcotráfico como um problema associado ou como aspectos do mesmo problema.

A leitura dos documentos produzidos pelo governo americano em 1994 sobre o tema do abate de aeronaves civis demonstra que a iniciativa dos programas de interdição aérea do Peru e da Colômbia nasceu de decisões internas dos dois países. $\mathrm{O}$ apoio de parte das autoridades americanas e mesmo de parlamentares não implicava a existência de consenso. Surgiram sérias dúvidas sobre as implicações internacionais e nacionais sobre a legalidade do auxílio norte-americano e sobre o conflito com a consolidada posição dos EUA em rejeitar o uso de força contra aeronaves civis'.

Se, por um lado, as estratégias baseadas no modelo de guerra às drogas, na oferta de informaçôes de radar e no apoio técnico e financeiro propiciavam as condições para os programas de interdição aérea de países aliados, por outro, havia o risco de repercussão negativa no campo político e jurídico diante da destruição de aeronaves civis e da possibilidade da morte de pessoas inocentes.

Em 1993, o Peru iniciou a implementação da norma que autorizava a destruição de aeronaves civis em voo e em 1994 o governo colombiano informou ao Departamento de Estado americano sobre as mesmas intenções. Os dois países foram alertados pelos americanos que não poderiam utilizar as informações para atacar aeronaves civis; porém, a política de interdição aérea associada ao abate de aeronaves continuou (Huskisson 2005, 113-114).

Ao prover informaçôes e disponibilizar seu aparato militar para ações destinadas a abater aeronaves civis, as autoridades americanas corriam risco de enquadramento das suas atividades dentro da lei contra sabotagem de aeronaves (Aircraft Sabotage Act) de 1984 (USA 1994e). As dúvidas sobre a legalidade do auxílio americano e sobre a responsabilidade de seus agentes envolvidos no

9 Ver Evans (2001) e USA (1994a; 1994b; 1994c; 1994d). 
monitoramento ${ }^{10}$ acarretaram a suspensão temporária da oferta de informaçóes em tempo real após o alerta dos advogados do Departamento de Justiça (USA 1994a; 1994b).

A limitação legal não interrompeu por muito tempo o auxílio americano. Ainda em 1994, uma lei aprovada pelo Congresso dos EUA concedeu imunidade aos agentes americanos e aos países envolvidos em operações de interceptação de aeronaves suspeitas de tráfico de entorpecentes ${ }^{11}$. Os requisitos para a imunidade consistiam: na suspeita razoável do envolvimento da aeronave no tráfico ilícito de entorpecentes; a determinação prévia do presidente norte-americano de que o tráfico no país onde ocorreria a interceptação representa séria ameaça à segurança nacional americana; a existência de procedimentos seguros para a prevenção de riscos contra a perda de vidas inocentes (USA 1995b).

A velocidade da tramitação da imunidade e os requisitos para sua aplicação revelam a importância dada ao tema do abate e do combate ao tráfico nas políticas de segurança norte-americanas para a América do Sul. A análise das autoridades norte-americanas sobre os programas peruanos e colombianos de abate mostrava-se extremamente positiva e os temores iniciais sobre as repercussões internacionais cederam espaço diante da opção estratégica da administração Clinton pelo fortalecimento das políticas antidrogas dos dois países. A concessão de imunidade aos americanos envolvidos nas operações de abate encerrou a fase de discussões e resistências internas sobre o modelo de interdição aérea implementado por Peru e Colômbia.

O programa de abate de aeronaves civis suspeitas de envolvimento no tráfico de entorpecentes recebeu das autoridades militares americanas o nome de Air Bridge Denial Program (ABDP). A criação do ABDP vinculava-se diretamente ao reconhecimento das Forças Armadas Revolucionárias da Colômbia (FARC) e do Sendero Luminoso (SD) como ameaças à segurança nacional dos EUA. A guerra às drogas representaria parte da luta contra as fontes de financiamento dos grupos guerrilheiros em atuação na América Latina (Huskisson 2005, 109).

O suporte a operações dessa natureza encontram justificativa na nova ênfase dada às ações realizadas nos países produtores e distribuidores de drogas. A mudança foi sintetizada na Diretiva Presidencial 14, lançada pelo presidente Clinton em 1993. Os programas antidrogas dos EUA deveriam atuar agora em três vertentes:

10 O argumento do Departamento de Justiça foi sintetizado da seguinte forma: "The Aircraft Sabotage Act of 1984 applies to the police and military personnel of foreign governments. In particular, the Act applies to the use of deadly force by such foreign governmental actors against civil aircraft in flight that are suspected of transporting illegal drugs. There is accordingly a substantial risk that United States Government officers and employees who provide flight tracking information or certain other forms of assistance to the aerial interdiction programs of foreign governments that have destroyed such aircraft, or that have announced an intent to do so, would be aiding and abetting conduct that violated the Act" (EUA 1994e, on line).

11 A lei estabelecia que: "National Defense Authorization Act for Fiscal Year 1995 (S. 2182) [...] SEC. 1012. Official immunity for authorized employees and agents of the United States and foreign countries engaged in interdiction of aircraft used in illicit drug trafficking." (USA, 1995b) 
assistência para que os países-fonte combatessem as causas da produção e tráfico de drogas; combate internacional às organizaçôes criminosas ligadas ao tráfico e programas de interdição seletiva e flexível nas regiões produtoras, de trânsito e próximas da fronteira (USA, 1993). O ABDP enquadra-se exatamente na terceira vertente e deveria conter a "ponte aérea" que interligava a vasta cadeia de produção e distribuição de drogas em áreas de difícil acesso do Peru e da Colômbia.

A necessidade da existência de programas de interdição aérea, como o $\mathrm{ABDP}$, devia-se às peculiaridades do complexo jogo entre repressão e resposta dos traficantes. A produção de cocaína depende das condições ambientais encontradas em áreas específicas à Amazônia, naturalmente localizadas em regiōes de acesso limitado. A intensificação das ações repressivas acarretava sucesso localizado na redução da produção ou do transporte da droga, mas vinha acompanhada imediatamente da reorganização dos arranjos produtivos. A principal estratégia desenvolvida pelos traficantes consistia em atuar nas regiōes de acesso mais difícil e interligar a rede de distribuição e produção por meio de um sistema de transporte que inclui pequenos avióes.

O maior controle sobre os voos interligando Peru e Colômbia acabava por ampliar a presença de transporte terrestre e o deslocamento para regiōes em que as ações de combate ao tráfico se mostrassem menos intensas ou eficazes (Forero 2003). As características da Amazônia brasileira não a habilitam como produtora de cocaína; contudo, a ligação fronteiriça com o Peru, a Colômbia e a Bolívia favorece a integração do País nas rotas de distribuição da droga (USA 2000). Sua inserção na cadeia de produção e distribuição, associada ao problema do tráfico na fronteira com o Paraguai, colocava o Brasil como um sério candidato a integrar, juntamente com Colômbia e Peru, o grupo de países envolvidos no programa de interdição aérea apoiado pelos EUA.

Em resumo, os programas que autorizam o abate de aeronaves civis apresentam como ponto de partida a concepção de guerra às drogas criada e difundida pelos EUA. Não obstante, justificavam-se para alguns países latino-americanos na necessidade de combater o narcotráfico como um problema associado às guerrilhas em atuação na Região Amazônica. Logo, a análise da introdução da Lei do Abate no Brasil não pode deixar de contemplar as preocupações dos militares brasileiros acerca da defesa territorial da Amazônia em face dos riscos derivados da ligação entre o narcotráfico e a guerrilha.

\section{A tragédia no Peru e as mudanças no ABDP}

No cenário internacional, ocorreu uma tragédia de grande repercussão quando, em 20 de abril de 2001, um hidroavião Cessna foi abatido por engano, acarretando a morte de Verônica Bowers, de 35 anos, e de sua filha Charity, um bebê de 7 meses de idade (Maierovitch 2003). O voo, pilotado por Kevin 
Donaldson, partiu da cidade peruana de Islândia com destino a Iquitos levando um casal de missionários batistas norte-americanos e suas duas filhas (Folha on-line e Reuters 2001).

Uma investigação conjunta realizada por diversas agências e instituições dos EUA, incluindo CIA, Departamento de Defesa e Departamento de Estado, além do governo do Peru, atribuiu a causa do acidente a uma série de deficiências nos procedimentos do programa, a erros dos envolvidos, à sobrecarga nos sistemas de comunicação e a dificuldades idiomáticas, entre outros fatores ${ }^{12}$. As características da rota utilizada e a forma como se desenvolveu o voo, associadas a informaçôes sobre atividades ilícitas coletadas continuamente, levantavam suspeitas sobre o uso do hidroavião abatido para o tráfico de drogas (USA 2001).

As investigaçôes constataram que o copiloto de um caça peruano transmitiu corretamente o número de inscrição do Cessna interceptado (OB-1408) antes de abatê-lo. Os integrantes do avião de vigilância norte-americano e do caça peruano que o acompanhavam não ouviram a comunicação porque estavam ocupados com outras transmissōes pelo rádio. Some-se a isso o fato de as aeronaves e armamentos da Força Aérea Peruana utilizadas no programa não permitirem tiros precisos direcionados para áreas não vitais. Durante o procedimento, o piloto do OB-1408 sequer ouviu as rajadas de advertência (USA 2001).

O governo norte-americano, pressionado pela opinião pública e pelo Congresso, resolveu suspender o programa de monitoramento de aeronaves suspeitas de narcotráfico na região andina (Maierovitch 2004), além de ter que indenizar os familiares das vítimas do Cessna abatido (Scolese 2004). A interrupção do ABDP não levou à interrupção do suporte dos EUA a outros programas destinados ao combate do narcotráfico e da guerrilha no Peru e na Colômbia.

A retomada do programa ocorreu após o pedido do presidente da Colômbia, Álvaro Uribe, para a ampliação do financiamento e do apoio norte-americanos no combate à guerrilha e ao narcotráfico em 2003. A iniciativa conjunta dos dois países representava um desdobramento do Plano Colômbia iniciado em 2000, sob as presidências de Andrés Pastrana (Colômbia) e Bill Clinton (EUA). O plano envolveu amparo financeiro inicial de cerca de US\$ 1,3 bilhôes por parte dos EUA, oferta de aeronaves, treinamento militar e amplo suporte de diversas agências norte-americanas (Veillete 2005, 1-3). A adesão americana ao plano tornava clara a sintonia entre as políticas e estratégias de endurecimento defendidas publicamente pelos presidentes colombianos, especialmente no governo de Álvaro Uribe, e as políticas de defesa dos EUA que integravam a guerra às drogas como um aspecto da segurança nacional norte-americana.

A análise superficial da influência do modelo de guerra às drogas norteamericano sobre países da América Latina pode levar a concluir pela existência de uma relação de mera submissão ou subordinação aos interesses dos EUA. Contudo,

12 O relatório final sobre a investigação, apesar do acidente, também destaca a importância e os sucessos do ABDP. 
o temor da perda do controle para os traficantes sobre porçóes distantes e isoladas do seu território e da associação com movimentos guerrilheiros fortaleceram e estimularam a ação governamental antidrogas no México, na Colômbia e no Peru nos anos de 1970 e 1980. A defesa da soberania nacional apresentava-se sempre como o mais forte fator para que os países aceitassem ou mesmo pedissem o suporte dos EUA aos programas de combate ao narcotráfico, não se podendo falar de simples submissão às gestôes norte-americanas (Jones 1998).

A leitura dos relatórios oficiais produzidos para prestar contas ao Congresso dos EUA ou para orientar os debates nas comissões parlamentares sobre os gastos com os programas antidrogas revelam a constante demanda dos países produtores por mais recursos para auxiliar em iniciativas como o ABDP ou para o treinamento de unidades militares ${ }^{13}$. A manutenção do suporte financeiro norte-americano para operações na região andina e nos países fronteiriços dependia de um conjunto amplo de fatores como a demonstração de interesse do governo aliado em continuar recebendo recursos, a avaliação sobre interesse estratégico para a segurança nacional dos EUA e as políticas desenvolvidas pelo país recebedor.

O reinício do ADBP ocorreu apenas em 2003, após a elaboração de um acordo (Term of Agreement) entre os EUA e a Colômbia sobre procedimentos de segurança para impedir a perda de "vidas inocentes". Todo o processo de rastreamento, identificação das aeronaves e das rotas, verificação das situações suspeitas e a operação de interdição e abate aconteceriam com a participação de militares americanos ou com equipes de empresas privadas americanas contratadas pelo Departamento de Estado (USA 2005).

Uma das mudanças mais importantes consistiu na passagem do controle do programa, antes sob a responsabilidade da CIA, para o Departamento de Estado, com a colaboração do Departamento de Defesa dos EUA. Ao mesmo tempo, contratou-se uma nova empresa responsável pelo suporte ao programa na Colômbia, assumindo o contrato a empresa Arinc, tradicionalmente vinculada aos programas do Departamento de Estado (USA 2005; Risen 2002; Arinc 2007).O processo revela a estratégia de utilizar empresas privadas norte-americanas nas operações antidrogas e no combate à guerrilha, de modo a reduzir a visibilidade e os riscos da participação direta de militares dos EUA em açōes no território colombiano (Marquis 2001).

Estabeleceu-se uma rígida sequência de procedimentos realizados sob a vigilância de três monitores de segurança norte-americanos: um situado no Joint Interagency Task Force-South (JIATF-South), em Key West, na Flórida, outro localizado no Centro de Comando da Força Aérea colombiana em Bogotá, e outro a bordo de uma aeronave de vigilância. A qualquer momento das operações, os monitores poderiam abortar a missão, ou, em caso de divergência com os militares colombianos, suspender a cooperação e a oferta de informações (USA 2005, 4-12).

13 Ver Veillette (2006; 2005) e USA (2005). 
Uma série de medidas visava a repelir as críticas de dentro dos EUA em relação ao suporte norte-americano à luta contra a guerrilha e o narcotráfico na Colômbia. As mudanças do programa ABDP para o Departamento de Estado representavam apenas uma parte do esforço que incluía a necessidade de formação em direitos humanos para as unidades militares colombianas que recebessem auxílio dos EUA e a criação de protocolos mais claros de segurança contra mortes de inocentes. Não obstante, a retomada do abate de aeronaves inseria-se num contexto de acirramento da militarização das políticas antidrogas para a América Latina, agora marcado pela definição dos movimentos guerrilheiros e dos traficantes como "narcoterroristas".

A longa trajetória da política de guerra às drogas ganhou desde 2003 seu contorno mais incisivo. O cenário pós-11 de setembro permitiu a justificativa necessária para a ampliação da presença norte-americana na América Latina. Não obstante a defesa das autoridades dos EUA quanto ao sucesso do ABDP, a análise sobre o impacto das políticas de abate na Colômbia está longe de mostrar qualquer consenso. O efeito imediato do maior controle do espaço aéreo consistiu no deslocamento das rotas aéreas para as regiões limítrofes na fronteira entre Brasil, Colômbia, Peru e Venezuela. Nessas áreas, as dificuldades operacionais para combater os voos ilegais associam-se aos problemas legais e políticos para realização de ações militares.

A maior eficácia da interdição aérea dependeria da articulação de todos os países situados numa grande área que cobre Brasil, Colômbia, Peru, Bolívia, Venezuela e Equador. A grande capacidade do tráfico de se adaptar às restriçōes causadas pelo ABDP no Peru e na Colômbia, com o deslocamento das rotas suspeitas para as áreas de fronteira, revelava a necessidade de incorporar novos países ao programa de abate. Assim, a compreensão do advento da Lei do Abate no Brasil exige a reflexão sobre as repercussões das políticas antidrogas e de defesa dos EUA para a América Latina, mas não pode deixar de perceber a complexidade de um programa de interdição com reflexos diretos sobre o controle do espaço aéreo em toda a Região Amazônica.

\section{A Lei do Abate no Brasil}

A justificativa oficial para a proposição da Lei do Abate brasileira encontra-se na exposição de motivos no C-004/GM-3, de 3 de novembro de 1995, assinada pelos então ministros Nelson Jobim, da Justiça, e Mauro José Miranda Gandra, da Aeronáutica (Brasil 1996a, 03063). O projeto respaldava-se em normas internacionais e "na legitimidade do direito de exercer a soberania no espaço aéreo sobrejacente aos territórios dos Estados, bem como das respectivas áreas marítimas". $\mathrm{Na}$ ordem interna, a legislação forneceria o embasamento para impedir o uso de "aeronaves e outros engenhos aéreos, para prática de atos hostis ou atentatórios contra a segurança da Nação Brasileira" [sic]. 
O documento trata da dificuldade de adotar procedimento coercitivo contra aeronaves suspeitas em virtude do texto do Código Brasileiro de Aeronáutica (CBA) não traduzir com a "devida clareza" a ideia de que, em situaçôes extremas, sejam aplicadas às aeronaves infratoras, ainda que civis, "medidas rigorosas". Por fim, alegando a sua indispensabilidade como fator de inibição no combate a ilícitos internacionais, os Ministros submetiam a proposta de projeto de lei à apreciação do Chefe do Executivo, cujo texto introduz modificação ao art. 303 da lei federal 7.565/86 (CBA), transcrito a seguir:

Art. $1^{\circ}$. Inclui-se, no art. 303, da Lei ${ }^{\circ} 7.565$, de 19 de dezembro de 1986, um novo $₫ 2^{\circ}$, renumerando-se o atual $2^{\circ}$ como parágrafo $3^{\circ}$;

Art. 303.

$\$$ “ $2^{\circ}$. Esgotados os meios coercitivos legalmente previstos, a aeronave será classificada como hostil, ficando sujeita à medida de destruição, na forma da legislação específica.”.

Art. $2^{\circ}$. Esta Lei entra em vigor na data de sua publicação.

O então Presidente da República Fernando Henrique Cardoso enviou ao Congresso Nacional, por meio da mensagem 1.183, o Projeto de Lei 1.229/95, cujo trâmite previa, preliminarmente, a aprovação pelas Comissões de Defesa Nacional, de Constituição e Justiça e de Viação e Transportes (Brasil 1996b, 18140-18142).

O deputado Domingos Dutra apresentou proposta de emenda modificativa justificando que a destruição de aeronave, em tempos de paz, trata-se de ato gravíssimo e, portanto, deveria ser tomada apenas pela mais alta autoridade brasileira, o Presidente da República, em razão da defesa da soberania (Câmara dos Deputados 2007). A emenda oferecida pelo parlamentar limitaria a competência para a ordem de tiro exclusivamente ao Presidente da República, sem possibilidade de delegação. Na prática, a emenda desnaturaria as pretensões do projeto, pois acarretaria uma cadeia de comando longa, complexa e demorada, com a palavra final sobre o abate recaindo sobre uma autoridade civil.

O relator do parecer da Comissão de Defesa Nacional, deputado Elton Rohnelt, entendendo que a pretensão contida na proposição do Executivo era "absolutamente oportuna e relevante" para o aperfeiçoamento do CBA e atinente à defesa do espaço aéreo nacional, posicionou-se pela aprovação do projeto de lei. Decidiu, contudo, considerar prejudicada a emenda apresentada pelo deputado Domingos Dutra, tendo em vista que a mesma estava contida na abrangência da emenda proposta pelo deputado José Genoíno (Câmara dos Deputados 2007).

O substitutivo apresentado pelo deputado José Genuíno serviu de base para a redação final da Lei do Abate. Atribuía ao Presidente da República a competência para a ordem final de destruição, porém previa a possibilidade de delegação da responsabilidade a outra autoridade. Abria-se, assim, espaço para a plena regulamentação da matéria por meio de simples decreto presidencial, de maneira ainda mais flexível do que o texto original enviado à Câmara. A autorização para 
o abate de aeronave poderia ocorrer, em tese, mediante manifestação de qualquer autoridade designada pelo chefe do Poder Executivo Federal.

O projeto de lei tramitou em regime de urgência e seguiu para discussão no plenário da Câmara dos Deputados, mesmo havendo pendência de pareceres nas Comissões de Constituição e Justiça e de Viação e Transportes.

O deputado José Genoíno, sustentando a constitucionalidade do dispositivo, ofereceu parecer favorável ao projeto. Argumentou em seu texto que a proposta final restabelecia o princípio da autoridade civil uma vez que todas as salvaguardas foram asseguradas para que a decisão da destruição da aeronave não ficasse sujeita a uma autoridade militar local. Afirmou, ainda, que no caso de essa destruição não decorrer de situação extrema, o Presidente da República poderá ser criminalmente responsabilizado por um ato de "aventura e irresponsabilidade" (Brasil 1996c, 19115-19116).

Nos debates no plenário da Câmara, os ânimos alteraram-se, principalmente, com o pronunciamento do deputado Fernando Gabeira (Brasil 1996d, 1911719120) que se mostrou radicalmente contra a proposta apresentada, conforme se observa na transcrição abaixo:

Mandava a sensatez que eu não viesse mais à tribuna falar sobre o tema, mas estou vendo tanto a esquerda brasileira, tão imbuída de seus princípios humanitários, como a direita brasileira, tão imbuída dos seus princípios de livre comércio, decretarem a pena de morte para contrabandistas e para traficantes de drogas a partir de uma análise perversa, oriunda dos Estados Unidos. Com o fim da Guerra Fria, os Estados Unidos declararam que a nova guerra seria contra a droga e determinaram que o papel do Brasil seria interceptar os avióes que saíssem da América Latina em direção àquele país. Na verdade, o Congresso brasileiro, incapaz de defender o nariz das crianças que cheiram cola no Brasil, mete-se agora numa aventura bélica, para defender o nariz dos norte-americanos que cheiram cocaína. [...] Neste momento, o Congresso brasileiro, pressionado pelos Estados Unidos, está prestes a votar uma proposição bélica, retrógrada, que vai nos jogar no período da Guerra Fria. Só que agora os adversários não são mais os comunistas; são os traficantes de drogas e os contrabandistas. Sabemos, pela nossa história, que os adversários inicialmente são o traficante de drogas e o contrabandista, mas, amanhă, podem ser outros, como os não-cooperativos. E os aviōes serão derrubados.

Ao final, o projeto foi aprovado por maioria na Câmara dos Deputados e encaminhado ao Senado Federal na forma do regimento interno. No Senado Federal o projeto de lei tramitou sem demais controvérsias, passando pela Comissão de Relações Exteriores e pela Comissão de Constituição e Justiça, sendo finalmente sancionado em 5 de março de 1998. A redação final ficou assentada da seguinte maneira: 
Art. $1^{\circ} \mathrm{O}$ art. 303, da Lei $\mathrm{n}^{\circ} 7.565$, de 19 de dezembro de 1986, passa a vigorar acrescido de um parágrafo numerado como $\$ 2^{\circ}$, renumerando-se o atual $\$ 2^{\circ}$ como $\$ 3^{\circ}$, na forma seguinte:

Art. 303.

$\$ 2^{\circ}$ Esgotados os meios coercitivos legalmente previstos, a aeronave será classificada como hostil, ficando sujeita à medida de destruição, nos casos dos incisos do caput do artigo e após autorização do Presidente da República ou autoridade por ele delegada.

$\$ 3^{\circ} \mathrm{A}$ autoridade mencionada no $\$ 1^{\circ}$ responderá por seus atos quando agir com excesso de poder ou com espírito emulatório.

Art. $2^{\circ}$ Esta Lei entra em vigor na data de sua publicação.

Faltava, no entanto, a regulamentação pelo Presidente da República. Contra essa omissão, insurgiram-se em coro os senadores Renan Calheiros, Romero Jucá, Ramez Tebet e Moreira Mendes em pronunciamentos datados de 27 de novembro de 2000 (Senado Federal 2007).

O senador Renan Calheiros relembrou o caráter de urgência de que se revestiu a matéria quando da tramitação da Lei 9.614/98, razão pela qual participou, ainda em 1998, conjuntamente com os Ministérios da Justiça e da Aeronáutica, da elaboração de decreto regulamentador, malgrado já terem se passado dois anos e meio sem a devida apreciação pelo Palácio do Planalto. Ressaltou, da mesma forma, que a regulamentação da medida forneceria "instrumentos eficazes para que o País não seja um corredor indulgente ao narcotráfico nem ao contrabando". Por fim, faz apelo pessoal às autoridades competentes para a retomada imediata da regulamentação da lei.

O governo brasileiro, contudo, não mostrava qualquer empenho para pôr em prática a Lei do Abate e adiava indefinidamente a regulamentação da matéria. Segundo Walter Maierovitch (2006), enquanto exercia a função de Secretário Nacional Antidrogas, reuniu-se com o então Presidente Fernando Henrique Cardoso e o alertou sobre a consequência prática da nova lei. Para o secretário, haveria a introdução da pena de morte no Brasil. Afirmou, ainda, que o presidente correria o risco de se ver marcado pela responsabilidade de introduzir medida tão drástica no ordenamento jurídico brasileiro. $\mathrm{O}$ presidente teria então assegurado que não regulamentaria a nova lei, gerando, assim, sua ineficácia. Ao mesmo tempo, o Ministério das Relações Exteriores teria sido acionado pelo Presidente da República para tentar reduzir a pressão norte-americana em torno do tema.

Toda a polêmica em torno da tramitação da proposta e da regulamentação centrava-se em três vertentes: a primeira atribuía a concepção da Lei do Abate aos EUA e criticava amplamente o modelo de guerra às drogas com todas as suas consequências; a segunda atacava os vícios jurídicos da autorização para derrubar aeronaves civis; e, finalmente, a terceira ressaltava a importância da lei para a defesa da soberania nacional e para o combate ao narcotráfico. 
De modo estranho, enquanto a maior parte das discussões repercutiam os dois primeiros argumentos, pouco se avançava no debate sobre a temática claramente indicada na exposição de motivos enviada pelo Executivo. O terceiro argumento, fundado na importância da Lei do Abate para a garantia da soberania nacional e para a defesa da Nação brasileira parece ter sido acolhido com pouca resistência pelos parlamentares. Nas diversas versões do texto da lei e nas propostas de alteração, mantinha-se sempre o mérito da medida considerada por si importante. Patenteavase a aplicação pouco crítica de concepções bélicas, como a ideia de ato hostil, sobre aeronaves civis. Esse silêncio escondia o aspecto mais relevante para compreensão da versão brasileira do ABDP: as preocupaçôes militares com a Amazônia.

Os temores de uma possível "internacionalização" da Amazônia representam uma das principais preocupaçōes militares brasileiras nas últimas décadas. A Política de Defesa Nacional, anunciada em junho de 1999 durante o governo Fernando Henrique Cardoso, previu a Amazônia como grande prioridade estratégica do governo, referindo-se aos "bandos armados" que atuam na fronteira da Amazônia brasileira com outros países ${ }^{14}$. A Estratégia de Defesa Nacional lançada em 1996 pelo Governo Federal apresenta como um dos fios condutores a preocupação estratégica com a defesa da Amazônia brasileira. Contudo, a compreensão da política de defesa e dos planos das Forças Armadas do Brasil passa necessariamente pela análise da percepção difundida entre os militares sobre os riscos de uma intervenção internacional sobre a Região Amazônica ${ }^{15}$ (Martins Filho e Zirker 2000, 105-106; Martins Filho 2006).

A redefinição dos novos inimigos dos EUA no contexto do pós-Guerra Fria acrescentou elementos para a preocupações dos militares brasileiros quantos aos cenários de conflito envolvendo o País. A inclusão do narcotráfico como grande ameaça à segurança americana, associada à interpretação dos militares brasileiro quanto ao crescente debate sobre a importância da criação de instrumento internacional de preservação do meio ambiente, entre outros aspectos, estimulou os temores relacionados à soberania nacional na Região Amazônica (Martins Filho e Zirker 2000, 108-110).

A Lei do Abate apresenta um caráter ambíguo, ao contemplar simultaneamente as preocupações dos militares brasileiros com a integridade territorial do País, diante de cenários de conflitos que incluem as grandes potências, e as políticas norteamericanas de combate ao narcotráfico (ou narcoterrorismo). Sem a percepção

14 O texto da Política Nacional de Defesa de 1996 prevê: [...] 2.12. No âmbito regional, persistem zonas de instabilidade que podem contrariar interesses brasileiros. A ação de bandos armados que atuam em países vizinhos, nos lindes da Amazônia brasileira, e o crime organizado internacional são alguns dos pontos a provocar preocupação. [...] 5.1. Para a consecução dos objetivos da Política de Defesa Nacional, as seguintes diretrizes deverão ser observadas: $[\ldots]$ j) proteger a Amazônia brasileira, com o apoio de toda a sociedade e com a valorização da presença militar.

15 O anúncio da descoberta de grandes reservas de petróleo na chamada camada do pré-sal no litoral brasileiro condicionou mudança na orientação das preocupaçōes militares; contudo, a Amazônia continua figurando como grande prioridade estratégica. 
desses dois aspectos, não se poderá compreender o complexo e tenso processo de regulamentação do abate de aeronaves civis.

Os militares brasileiros desenharam uma nova doutrina cujo principal cenário consiste numa guerra não convencional longa e de baixa intensidade, que pode incluir conflitos com forças internacionais, com potências estrangeiras ou contra a guerrilha e os narcotraficantes (Martins Filho e Zirker 2000, 119-120; Martins Filho 2006). O desenho de um cenário de conflito dessa natureza contra forças como a guerrilha associada ao narcotráfico pressupóe a possibilidade de agir contra a rede aérea ilegal presente nas regiões de produção de droga. A hipótese de um conflito não convencional contra forças irregulares não caracterizadas como uma agressão aérea militar dificilmente poderia ser detida segundo as normas aplicáveis aos confrontos entre naçōes.

Para a Aeronáutica, a Lei do Abate ganha contornos ainda mais relevantes. Em diversas oportunidades, brigadeiros e o próprio comandante de Força Aérea trataram da autorização para o tiro de destruição como um verdadeiro pressuposto para o cumprimento da missão de proteger a soberania do espaço aéreo brasileiro ${ }^{16}$. Durante o intervalo entre a aprovação da lei em 1998 e a regulamentação em 2004, o tema produzia o acirramento de sentimentos nacionalistas, especialmente diante do uso de imagens e gravaçôes de descaso de pilotos diante da ordem dos militares para pousar ${ }^{17}$. O abate representava um ponto sensível para todos o militares, mas se revelava ainda mais importante para a redefinição do papel da Força Aérea Brasileira no planejamento da defesa do País.

Uma das etapas fundamentais da inserção da FAB no plano estratégico de ampliação da presença na região amazônica consistiu na criação do Sistema de Vigilância da Amazônia (Sivam), cujo sucesso dependia intensamente da capacidade de agir diante de violações ao espaço aéreo brasileiro. Revela-se sintomática a inexistência de registro de maior polêmica sobre a autorização do tiro de destruição quando da criação do ABDP pela Colômbia e pelo Peru e da própria idealização do Sivam. O debate público e a discussão parlamentar sobre a importância da Lei do Abate circunscreveu-se às necessidades de controle sobre a Amazônia brasileira.

A autorização de abate representa, assim, parte de um conjunto de medidas destinadas a ampliar a capacidade de acompanhar, vigiar e agir sobre a Região

16 Em texto explicativo sobre a Lei do Abate, a Força Aérea Brasileira ressalta a completa desobediência às determinaçôes de identificação e pouso dirigidas às aeronaves em voos clandestinos antes da regulamentação. O documento registra também que: "o Governo Brasileiro, decidido a reverter essa situação e aprimorar a defesa do país, vem desenvolvendo uma série de ações, como a transferência de efetivos militares para a Amazônia e a modificação da legislação brasileira no sentido de preparar as Forças Armadas para atuar contra os delitos transnacionais fronteiriços, no combate ao tráfico terrestre e fluvial." (Brasil FAB 2008). Em sentido oposto, o Brigadeiro Teomar Fonseca Quírico (2008) ressaltou em 2002: "O ponto a que desejo chegar é que a Lei do Abate não é a única maneira de a Força Aérea cumprir sua missão. E o que me preocupa é que estamos passando para os nossos oficiais, principalmente aqueles mais jovens, a impressão de que sem ela nada poderá ser executado."

17 A referência às imagens de pilotos ignorando as determinações de pouso emitidas pelos pilotos da FAB surgem recorrentemente nas manifestaçóes militares sobre o tema. Se por um lado o discurso da defesa da soberania surge para legitimar o abate, de outro as imagens de descaso desses pilotos reforçam a adesão dos militares à lógica contida em programas de interdiçãao aérea. 
Amazônica, que incluem redistribuição de efetivos, modernização de equipamento, criação de novas unidades e ênfase no treinamento de forças especiais, entre outras. A alteração legislativa compatibiliza a legislação aos planos militares para a área e às necessidades operacionais contidas no modelo estratégico para a defesa do País.

Essa orientação se mostra claramente na estratégia de comando da FAB para o período 2003-2006. Em paralelo às ações de modernização da Força Aérea, a estratégia prevê "a constante preocupação com a atualização organizacional", fundada em alguns elementos básicos, dentre os quais o "aumento da presença e da representatividade da Força Aérea na Amazônia, no Centro-Oeste e em importantes capitais do país" (NOTAER 2005, 10).

Por sua vez, a resistência dos EUA ${ }^{18}$ diante da Lei do Abate no Brasil alimentou a polêmica e os temores militares ${ }^{19}$. Desde o evento do ataque ao avião de missionários americanos no Peru, a postura norte-americana sobre o tema ganhou um compasso cauteloso. Retomou-se o temor inicial causado pelos alertas levantados do Departamento de Justiça sobre a ilegalidade do abate de aeronaves civis e sobre a contradição com as posições históricas dos EUA sobre o tema. Ao mesmo tempo, as restriçóes impostas após a tragédia no Peru subordinavam o reinício do ABDP na Colômbia à negociação de procedimentos de segurança cuja execução dependia da participação direta de militares dos EUA.

O principal argumento exposto publicamente para justificar a resistência originava-se no fato de os equipamentos do Sivam terem origem em empresas norteamericanas, o que acarretaria o risco de enquadramento na Lei Antissabotagem de Aeronaves desse país ${ }^{20}$. A autorização para a cooperação dos EUA em programas de interdição aérea dependia legalmente da elaboração de uma determinação presidencial atestando a existência de procedimentos capazes de impedir a perda de vidas inocentes. A solução seguida pela Colômbia revelava-se completamente inviável em face da exigência do acompanhamento direito dos procedimentos por militares norte-americanos. Sem um acordo sobre os procedimentos, não haveria autorização presidencial nos EUA e os procedimentos de abate poderiam receber

18 “[...] O ministro da Defesa, José Viegas, declarou publicamente no Congresso que a regulamentação só não saiu ainda porque os americanos restringem o comércio com países que adotam a política de derrubada de aeronaves não identificadas. A medida é considerada pelas autoridades brasileiras como necessária à repressão ao tráfico internacional de drogas [...]" (Passos 2003). "No dia 3 de setembro, o ministro da Defesa José Viegas e os brigadeiros Bueno e José Carlos Pereira (Comando Geral do Ar) estiveram reunidos com representantes do governo dos EUA; na pauta da conversa, a questão da Lei do Abate. Segundo uma fonte de Brasília, o governo americano insiste para que o Brasil não regulamente a lei. A mesma fonte assegura que a posição do ministro Viegas na reunião foi firme, no sentido de demonstrar que o governo do presidente Lula pretende regulamentar a Lei do Abate o mais rapidamente possível" (Drumond 2003).

19 "Para o Brigadeiro Cherubim Rosa Filho, não há fundamento nas restriçōes impostas pelos funcionários norte-americanos. O Brigadeiro indaga: Se perguntarem, no Congresso, para o que está servindo o Sivam na Amazônia o que vamos responder?" (Contreiras 2004).

20 Em visita ao Brasil em março de 2004, o General da Força Aérea dos EUA, Richard B. Myers, explicou ao ministro da Defesa, José Viegas, que: "the equipment used in shoot-downs is manufactured in the United States, and American law makes it a criminal offense for any U.S. citizen to participate in or support another country shooting down a civil aircraft unless it's permitted by a presidential determination” (Garamone 2004). 
tratamento criminal em tribunais norte-americanos, não se aplicando a imunidade concedida para o início do ABDP em $1994^{21}$.

A criação da Lei do Abate parece, assim, melhor entendida se encarada como um instrumento de controle permanente da Amazônia brasileira e de atuação para o enfraquecimento de potenciais ameaças. Inserido neste novo cenário estratégico, o abate revela uma natureza essencialmente bélica e não de combate ao crime organizado, apesar de lançar a força aérea num trabalho rotineiro de fiscalização do narcotráfico e do contrabando. Essa hipótese implica sérias dificuldades para enquadrar a nova lei numa análise constitucional ou ainda no campo do direito internacional aplicável à aviação. Nas duas áreas, a discussão levaria quase inevitavelmente à rejeição da possibilidade do abate, especialmente por não se poder aplicar um modelo de guerra para o combate ao crime em tempos de paz.

Em 2004, o então ministro José Viegas, responsável pela pasta da Defesa, asseverava ter encontrado a solução para o impasse mediante acordo com a Casa Branca sem, contudo, ceder às pressōes de Washington (Scolese 2004). O assunto foi discutido com o Secretário de Defesa norte-americano Donald Rumsfeld, especialmente quanto à coordenação das regras sobre o abate de aeronaves suspeitas de narcotráfico (Assis 2003, 39). Na ocasião, o Secretário informou que o governo dos Estados Unidos não mais repassaria informaçôes sobre voos suspeitos, devendo o Brasil contratar serviços privados.

Não obstante toda a controvérsia, o Presidente Lula regulamentou a Lei do Abate de aeronaves suspeitas de tráfico de entorpecentes em 16 de julho de 2004, ficando sua vigência postergada para 90 dias após a publicação do Decreto no 5.144 , o que se deu a partir do dia 17 de outubro de 2004. Na oportunidade do lançamento do Decreto, o ministro José Viegas (apud Silva 2004, 21) assim se manifestou: "O governo está sinalizando claramente sua disposição em combater, com as armas adequadas, a invasão de nossas fronteiras por quadrilhas internacionais de narcotraficantes."

Apenas Brasil e Colômbia contam hoje com programas de interdição aérea certificados pelo governo dos EUA (USA 2008, 3). As negociações brasileiras com as autoridades norte-americanas resultaram na elaboração de uma autorização presidencial em que se reconhece o narcotráfico como ameaça à segurança nacional brasileira e a existência de procedimentos seguros para a prevenção de perda de vidas inocentes. Ao contrário do programa colombiano, o Brasil não conta com participação direta do governo americano nos procedimentos de intercepção e abate. Não obstante, permanece a rotina das certificaçôes e autorizaçôes presidenciais previstas pela legislação dos EUA.

A discussão pública sobre a aplicação da Lei do Abate no Brasil e as manifestações após sua regulamentação reforçam a vinculação da sua existência com os projetos estratégicos de defesa da soberania nacional na Região Amazônica.

21 Sobre o assunto, ver notas 7 e 8 . 
Apesar de a justificativa do combate ao narcotráfico constar de todos os momentos, sobressai a preocupação com a defesa das fronteiras, com a ação de grupos armados na Amazônia e a leitura do narcotráfico como um problema de segurança nacional.

\section{Conclusões}

O fundamento para a legitimação do abate de aeronaves civis consiste na suspeita da participação desta no narcotráfico e não na ofensa efetiva à soberania. A pergunta sobre o que a aeronave não identificada está fazendo continua sem resposta e só será respondida após sua derrubada. No contexto da Guerra Fria, argumentava-se que a derrubada de aviōes civis se devia à violação do espaço aéreo; contudo, no abate brasileiro ou colombiano, não se trata efetivamente de violação do espaço aéreo, pois pode ocorrer inclusive com aviōes oriundos do próprio território nacional.

A construção das políticas de interdição aérea fundadas na possibilidade de abate nasce, em grande medida, de um processo gradual de afirmação do modelo norte-americano de guerra às drogas. Mais do que um recurso retórico, a guerra às drogas importou no incremento dos investimentos na repressão ao tráfico, na expansão da atuação militar dos EUA em países produtores e distribuidores de drogas, no estímulo à integração das forças armadas nacionais ao combate das organizações ligadas ao narcotráfico e no tratamento dessas organizações como ameaça à segurança nacional norte-americana.

A autorização para o ABDP contraria amplamente todos os pressupostos sobre os quais se estruturou a aviação civil no século 20. Essa possibilidade confronta-se, ademais, com a posição histórica dos EUA sobre o tema, a ponto de exigir a criação da imunidade legal para os norte-americanos que direta ou indiretamente auxiliarem nas operações de abate. Dessa forma, somente com elaboração de argumentos capazes de desviar a ideia de uso da força letal contra aeronaves civis das restriçóes legais e políticas, tornou-se possível manter o suporte às operaçōes realizadas por Peru e Colômbia contra a rede aérea a serviço da guerrilha e do narcotráfico.

A importância do modelo de guerra às drogas não pode obscurecer, contudo, a percepção dos programas do tipo ABDP como uma opção interna dos países envolvidos. A tendência a considerá-lo como uma imposição norte-americana não encontra substrato nos documentos e debates produzidos acerca do tema. A implementação das políticas de derrubada e aviōes suspeitos de envolvimento no tráfico liga-se às necessidades militares de Colômbia e Peru e às características da Região Amazônica. A importância do transporte aéreo em pequenos aviōes para a logística da guerrilha e do tráfico numa região ocupada por vastas extensões de floresta permite compreender melhor o uso do tiro de destruição contra aeronaves civis.

No caso brasileiro, a situação mostra-se ainda mais complexa. A existência de programas de interdição nos países fronteiriços desloca as rotas aéreas ilegais 
para as faixas de fronteira ou para o território brasileiro. Some-se a isso o fato de o Brasil funcionar como país distribuidor de drogas para os mercados internacionais e um grande mercado consumidor. Aparentemente, esse contexto justificaria a integração do País nos programas de abate. Não obstante, faltaria ainda o elemento mais importante para a sustentação e legitimação do ABDP brasileiro, a ameaça real à segurança nacional na forma de um conflito armado.

A opção brasileira pela Lei do Abate só pode ser compreendida adequadamente se cotejada com as percepçóes militares sobre as novas ameaças à soberania do País e sobre o papel das Forças Armadas após o fim da Guerra Fria e do Regime Militar. $\mathrm{O}$ resguardo da integridade territorial e a proteção à soberania nacional sobre a Amazônia brasileira surgem como pontos centrais dos projetos militares e dos planos estratégicos para a defesa do País.

A associação dos EUA com os programas de interdição aérea nos países vizinhos, diferentemente do que se poderia imaginar, acaba por produzir efeitos contraditórios. Se por um lado o modelo militarizado de guerra às drogas estimula a participação das Forças Armadas brasileiras no combate ao narcotráfico, por outro a presença militar norte-americana na Amazônia pode atiçar ainda mais os temores brasileiros sobre os riscos de uma intervenção internacional sobre a região.

Nos cenários estratégicos desenhados pelos militares brasileiros e no planejamento para a reorganização da defesa do País, desenha-se um conflito longo e de baixa intensidade na Região Amazônica contra uma potência militarmente superior. Assim, a criação da Lei do Abate no Brasil trouxe como argumento legitimador o combate ao tráfico de drogas; contudo, sua existência se mostra vinculada mais intensamente aos temores em torno da Amazônia e ao peso simbólico para os militares das pequenas violações rotineiras do espaço aéreo do que a eventuais pressões dos EUA ou ao efetivo efeito sobre o tráfico de drogas.

Os relatórios oficiais do governo norte-americano tendem a acentuar a importância do ABDP para o combate ao tráfico; contudo, os números expõem a ineficácia do programa em seu principal objetivo declarado, qual seja reduzir a oferta de drogas. O controle do espaço aéreo e a possibilidade de abate reduzem efetivamente os episódios de voos suspeitos ou ilegais; todavia, o narcotráfico rapidamente constrói alternativas, como o transporte terrestre e fluvial e a alteração de rotas aéreas. Nos casos brasileiro e colombiano, únicos países que ainda mantêm políticas de abate de aeronaves civis, houve o deslocamento do tráfico para os rios e para as fronteiras secas. No caso do transporte aéreo, há uma concentração de voos em áreas de fronteira, onde o abate gera risco de conflitos internacionais ou simplesmente se mostra inviável.

A ausência de registros de derrubada de aviōes civis pela FAB ou de mortes pacificou temporariamente a maior parte das críticas à Lei do Abate, principalmente no campo jurídico. Sua eficácia na redução de violações ao espaço aéreo e ao tráfico em pequenos avióes surge como trunfo para quem defende sua existência. Todavia, permanece em aberto o questionamento sobre efeitos concretos da autorização 
do uso de aparelhos militares e da retórica da guerra como instrumento de combate ao narcotráfico. Não se trata de opção simples e isenta de riscos. A Lei do Abate expõe, assim, apenas um fragmento da complexa tarefa de definir o verdadeiro papel das Forças Armadas brasileira dentro da democracia.

\section{Referências bibliográficas}

ARINC. (2007) ARINC Named a Prime Contractor on DoD's Anti-Drug/Terrorism Program. Disponível em: <http://www.arinc.com/news/2007/09-11b-07.html>. Acesso em: 21 de abril de 2008 .

ASSIS, Jorge César de. (2003) Interceptação e abate de aeronave, consideraçôes sobre a Lei no. 9.614/98. Revista Jurídica Consulex, São Paulo, Ano VII, n. 163, 31 de outubro de 2003.

BERTRAM, Eva et al. (1996) Drug War Politics: the price of denial. Berkley and Los Angeles: University of California Press, 1996.

BAUM, Dan. (1996) Smoke and Mirrors: The War on Drugs and the Politics of Failure. 1 ed. Sem local, Sem editora, 1996.

BEATY, Douglas R. (1996) National Drug Control Strategy: a strategic analysis. Carlisle Barracs: US Army War College, 1996.

BRASIL. (1996a) Diário da Câmara dos Deputados. Brasília, p. 03063, 2 de fevereiro de 1996a.

. (1996b) Brasília, pp. 18140-18142, 26 julho de 1996b.

. (1996c) Brasília, pp. 19115-19116, 4 de julho de 1996c.

(1996d) Brasília, pp. 19117-19120, 4 de julho de 1996d.

BRASIL. Força Aérea Brasileira - FAB. (2008) Entenda a lei do tiro de destruição. Disponível em: <http://www.fab.mil.br/imprensa/Noticias/lei-abate/3007_abate.htm>. Acesso em: 19 de maio de 2008.

BRASIL. Presidência da República. (2008) Decreto n. 6703, de 18 de dezembro de 2008. Aprova a Estratégia Nacional de Defesa, e dá outras providências. Publicado no Diário Oficial da União em 19 de dezembro de 2008. Disponível em: <http://www.fab.mil.br/portal/defesa/ estrategia_defesa_nacional_portugues.pdf>. Acesso em 5 de maio de 2009.

BUSH, George H. W. (1989) President's Speech on National Drug Control Strategy. The New York Times, Nova Iorque, 6 de setembro de 1989. Discurso proferido em rede nacional de TV para lança a Estratégia Nacional Antidrogas. Disponível em: <http://query.nytimes. $\mathrm{com} / \mathrm{gst} /$ fullpage.html? res=950DE2DA163BF935A3575AC0A96F948260>. Acesso em: 26 de fevereiro de 2008.

CÂMARA DOS DEPUTADOS. (2007) Tramitação das Proposições: PL 1229/1995. Disponível em: <http://www.camara.gov.br>. Acesso em: 17 de novembro de 2007.

CARPENTER, Ted Galen. (2003) Bad Neighbor Policy: Washington's Futile War on Drugs in Latin America. Nova Iorque: Editora Palgrave Macmillan, 2003.

CONTREIRAS, Hélio. (2004) Militares defendem Lei do Abate. Jornal do Brasil, 14 de julho de 2004. Disponível em: <http://www.defesanet.com.br/fab/jb12jul04/>. Acesso em 13 de julho de 2008. 
EVANS, Michael L. (2001) Shootdown in Peru: The Secret U.S. Debate Over Intelligence Sharing with Peru and Colombia. National Security Archive Electronic Briefing Book No. 44. Washington, 2001. Disponível em: <http://www.gwu.edu/ nsarchiv/NSAEBB/NSAEBB44/>. Acesso em 10 de maio de 2008.

FOLHA ONLINE - REUTERS. (2001) Relatório explica razão de ataque equivocado a aviāo no Peru. Washington, 2 de agosto de 2001. Disponível em: <http:www1.folha.uol.com.br/folha/ reuters/ult112u4198.shl> Acesso em 27/09/2005.

FORERO, Juan. (2003) U.S. Backs Colombia on Attacking Drug Planes. The New York Times, August 20, 2003. Disponível em: <http://query.nytimes.com/gst/fullpage.html?res=9804EF DD1E30F933A1575BC0A9659C8B63\&sec=\&spon=\&pagewanted=all $>$. Acesso em: $21 \mathrm{de}$ abril de 2008.

DRUMOND, Cosme Degenar. (2003) O que vai pelo mercado? Defesanet, 16 de setembro de 2003. Disponível em: <http://www.defesanet.com.br/noticia/militares2/>. Acesso em 13 de maio de 2005.

GARAMONE, Jim. (2004) Myers Discusses Haiti, Terrorism, Brazil's Shoot-Down Policy. American Forces Press Service. 11 de março de 2004. Disponível em: <http://www.defenselink. $\mathrm{mil} /$ news/newsarticle.aspx?id=2709413>. Acesso em 13 de maio de 2008.

GUÁQUETA, Alexandra. (2005) Change and continuity in U.S.-Colombian Relations and the war against drugs. Winter, 2005 THE JOURNAL OF DRUG ISSUES [0022-0426/05/01 27-56] p. 27-56.

HUSKISSON, Darren. (2005) The air bridge denial program and the shootdown of civil aircraft under international law. Air Force Law Review, Washington DC, Vol. 56, p. 109-166, 2005.

JAMES RISEN. (2002) U.S. set to resume its role in halting latin drug planes. The New York Times, July 4, 2002. Disponível em: <http://query.nytimes.com/gst/fullpage.html?res=9C05E EDF1331F937A35754C0A9649C8B63.> Acesso em 21 de abril de 2008.

JONES, Hal. (1998) The limits of pressure. Harvard International Review, Cambridge, V. 20, Issue 2, p. 38-41, Spring, 1998.

MAIEROVITCH, Walter Fanganiello. (2003) Pena de morte no Brasil. Revista Carta Capital, 23 de julho de 2003.

(2004) Licença para matar, com o tiro de abate e de afundamento, Lula introduz a pena de morte no Brasil. Revista Carta Capital. Disponível em: <http://www.cartacapital.com. br/edicoes/2004/07/301/1611 >. Acesso em: 05/10/2005.

(2006) Entrevista concedida no programa Roda Viva da TV Cultura. São Paulo, em 17 de abril de 2006.

MARQUIS, Christopher. (2001) Inquiry on Peru Looks at a C.I.A. Contract. The New York Times, April 28, 2001. Disponível em: <http://query.nytimes.com/gst/fullpage.html?res=9A0 1E3D71039F93BA15757C0A9679C8B63>. Acesso em 1 de julho de 2008.

MARTINS FILHO, João Roberto. (2006) As forças armadas brasileiras no pós-guerra fria. Tensões Mundiais: revista do Observatório das Nacionalidades, Fortaleza, v. 2, n. 3, p. 78-135, jul/dez., 2006.

MARTINS FILHO, João Roberto; ZIRKER, Daniel. (2000) Nationalism, National Security, and Amazonia: Military Perceptions and Attitudes in Contemporary Brazil. Armed Forces \& Society, Vol. 27, No. 1, Fall, 2000, pp. 105-129. 
NIXON, Richard. (1969a) Statement Outlining Actions and Recommendations for the District of Columbia. 1969a. Disponível em: <http://www.nixonlibraryfoundation.org/clientuploads/ directory/archive/1969_pdf_files/1969_0020.pdf>. Acesso em: 18 de abril de 2008.

(1969b) Memorandum on the Narcotic and Dangerous Drug Traffic in the District of Columbia. 1969b. Disponível em: <http://www.nixonlibraryfoundation.org/clientuploads/ directory/archive/1969_pdf_files/1969_0063.pdf>. Acesso em: 18 de abril de 2008.

NOTAER. (2005) Estrutura Organizacional. Brasília, N. 16, 28 de setembro de 2005. Disponível em: <http://www.fab.mil.br/imprensa/notaer/2005/05not16/notaer16.pdf>. Acesso em: 20 de maio de 2008.

PASSOS, José Meirelles. (2003) Represália Americana. O Globo On Line. 2 de julho de 2003. Disponível em: <http://www.defesanet.com.br/noticia/usatpi1/>. Acesso em: 14 de maio de 2008.

PECENY, Mark; DURNAN, Michael. (2006) The FARC's Best Friend: U.S. Antidrug Policies and the Deepening of Colombia's Civil War in the 1990s. Latin American Politics \& Society, Miami, Vol. 48, Issue 2, p. 95-116, Summer, 2006.

PERL. Raphael F. (1997) Drug Control: International Policy and Options (88093). Washington: Congressional Research Service (CRS) - The Library of Congress, 1997. Disponível em: <http:// www.globalsecurity.org/intell/library/reports/crs/88-093.htm>. Acesso em 23 de maio de 2008.

. (2006) International Drug Trade and U.S. Foreign Policy. Washington: Congressional Research Service (CRS) - The Library of Congress, 2006. Disponível em: <http://italy. usembassy.gov/pdf/other/RL33582.pdf>. Acesso em: 23 de maio de 2008.

QUÍRICO, Teomar Fonseca. (2008) Lei do abate: problema ou solução? Disponível em: <http:// www.defesanet.com.br/noticia/leidoabate/>. Acesso em: 18 de maio de 2008.

RISEN, James. (2002) U.S. set to resume its role in halting latin drug planes. The New York Times, July 4, 2002. Disponível em: <http://query.nytimes.com/gst/fullpage.html?res=9C05E EDF1331F937A35754C0A964>. Acesso em: 1 de julho de 2008.

RODRIGUES, Thiago M. S. (2002) A infindável guerra americana: Brasil, EUA e o narcotráfico no continente. São Paulo em Perspectiva, v. 16, n. 2, p. 102-11, 2002. Disponível em: <http:// www.scielo.br/scielo.php?script=sci_arttext\&pid=S0102-8392002000200012\&lng=pt\&nrm $=$ iso $>$. Acesso em: 11 de novembro 2007.

SCHNAUBELT, Christopher M. (1994) Can the military's effectiveness in the drug war be measured? CATO Journal, v. 14, n. 2, p. 243-265, Fall, 1994. Disponível em: <http:// search.ebscohost.com/login. aspx? direct=true \&db=afh\&AN=9510075087\&amp;lang=ptbr\&site=ehost-live $>$. Acesso em: 28 de janeiro de 2008.

SCOLESE, Eduardo. (2004) Pressão dos EUA dificultou a regulamentação. Folha Online Brasil. Brasília, 19 de julho de 2004. Disponível em: <http://www1.folha.uol.com.br/folha/ brasil/ult96u62531.shtml> Acesso em: 21 de setembro de 2005.

SENADO FEDERAL. (2007) Pronunciamentos. Disponível em: <http://www.senado.gov.br/ sf/atividade/Pronunciamento/detTexto.asp?t=313157>. Acesso em: 14 de novembro de 2007.

SILVA, Alessandro. (2004) Para proteger nossas fronteiras. AEROVISÃO: revista oficial da Força Aérea Brasileira. n. 211, jul./set., 2004, p. 20-22.

USA. (1984) National Security Decision Directive $n^{\circ}$ 138: Combating Terrorism (NSDD-138). 26 de abril de 1984. Disponível em: <http://www.fas.org/irp/offdocs/nsdd/nsdd-138.htm>. Acesso em: 11 de março de 2008.

USA. (1993) Office of the Press Secretary. Presidential Decision Directives - PDD 14. November, 3. Disponível em: <http://www.fas.org/irp/offdocs/pdd14.htm>. Acesso em: 15 de abril de 2008. 
USA. (1994a) Department of State, Office of the Legal Adviser. Forcedown Policy: Options for Colombia and Peru (secret). February 9, 1994a. Disponível em: <http://www.gwu.edu/ $\sim$ nsarchiv/ NSAEBB/NSAEBB44/doc2.pdf>. Acesso em: 10 de maio de 2008.

USA. (1994b) Embassy Lima. Suspension of Provision of DOD Real-time Radar Track Data to Peru (secret). May 6, 1994b. Disponível em: <http://www.gwu.edu/ nsarchiv/NSAEBB/ NSAEBB44/doc5.pdf>. Acesso em: 10 de maio de 2008.

USA. (1994c) Department of State, Bureau of International Narcotics Matters. Talking Points: Implication of DOD's Forcedown Decision (confidential). May 9, 1994c. Disponível em: <http:// www.gwu.edu/ nsarchiv/NSAEBB/NSAEBB44/doc6.pdf>. Acesso em: 10 de maio de 2008.

USA. (1994d) Department of State. Action Memorandum - Use of Weapons Against Civil Aircraft (secret). May 10, 1994d. Disponível em: <http://www.gwu.edu/ nsarchiv/NSAEBB/ NSAEBB44/doc7.pdf>. Acesso em 10 de maio de 2008.

USA. (1994e) Department of Justice. United States assistance to countries that shoot down civil aircraft involved in drug trafficking. July 14, 1994e. Disponível em: <http://www.usdoj.gov/olc/ shootdow.htm>. Acesso em: 11 de março de 2008.

USA. 1995a The White House. A National Security Strategy of Engagement And Enlargement. Washington,. Disponível em: <http://www.au.af.mil/au/awc/awcgate/nss/nss-95.pdf>. Acesso em: 4 de março de 2008.

USA. (1995b) National Defense Authorization Act for Fiscal Year 1995 (S. 2182). SEC. 1012. 1995b. Disponível em: <http://www.fas.org/irp/congress/1994_rpt/s2182-1012.html.> Acesso em: 13 de março de 2008.

USA. (2000) Department of State. Bureau for International Narcotics and Law Enforcement Affairs. International Narcotics Control Strategy Report (INCSR). Washington, March 1, 2000. Disponível em: <http://www.state.gov/p/inl/rls/nrcrpt/1999/903.htm>. Acesso em: 15 de novembro de 2007.

USA. (2001) Department of State. Bureau for International Narcotics and Law Enforcement Affairs. Peru investigation report: the april 20, 2001 peruvian shootdown accident. Washington, August 2, 2001. Disponível em: <http://www.fas.org/irp/news/2001/08/peru_shootdown. html>. Acessado em: 18/02/2006.

USA. (2002) United States Southern Command (USSOUTHCOM). Media support information and fact sheet, 2002. Disponível em: <http://www.southcom.mil/PA/Media/Releases/Plan\%20 Colombia\%20Programs\%20Fact\%20Sheets.pdf>. Acesso em 9 de maio de 2008.

USA. (2005) United States Government Accountability Office - GAO. Drug control: Air Bridge Denial Program in Colombia Has Implemented New Safeguards, but Its Effect on Drug Trafficking Is Not Clear (GAO-05-970). 2005. Disponível em:<www.gao.gov/cgi-bin/ getrpt?GAO-05-970>. Acesso em 21 de abril de 2008.

USA. (2006) Office of the Press Secretary. Statement on U.S. Drug Interdiction Assistance to the Government of Colombia. 2006. Disponível em: <http://www.whitehouse.gov/news/ releases/2006/08/print/20060817-8.html>. Acesso em 21 de abril de 2008.

USA. (2008) Report relating to the interdiction of aircraft involved in illicit drug trafficking. Washington: U.S. Government Printing Office, 2008.

VEILLETE, Connie. (2005) Andean Counterdrug Initiative (ACI) and Related Funding Programs: FY2005 Assistance (RL32337). Washington: Congressional Research Service (CRS), 2005. Disponível em: <http://www.au.af.mil/au/awc/awcgate/crs/rl32337.pdf>. Acesso em: 21 de abril de 2008. 
WEEKS, Gregory. (2006) Fighting terrorism while promoting Democracy: competing priorities in U.S. Defense policy toward Latin America. Journal of Third World Studies, Vol. XXIII, No. 2, 2006, p. 59-77.

\author{
Recebido em 11 de setembro de 2011 \\ Aprovado em 11 de janeiro de 2012
}

\title{
Resumo
}

O presente artigo analisa o processo de criação e regulamentação da Lei do Abate no Brasil, que autoriza a derrubada em pleno voo de aeronaves civis suspeitas de envolvimento no tráfico de drogas. Investigam-se as relações entre a elaboração da Lei do Abate, a política de guerra às drogas propagada pelos EUA e as preocupações estratégicas dos militares brasileiros acerca da segurança da Região Amazônica. Como parte da contextualização da criação dos programas de interdição aérea baseados no abate de aeronaves, estudam-se as origens e as transformações das políticas antidrogas dos EUA desde a década de 1960 e o modelo de guerra às drogas (War on Drugs). Analisa-se também o processo de discussão parlamentar no Brasil sobre a Lei do Abate e os debates para a sua regulamentação. A pesquisa ocorreu por meio da análise de documentos produzidos pelos governos dos EUA (abertos e sigilosos reclassificados) e do Brasil, da investigação dos anais do Congresso Nacional e do estudo de livros e artigos científicos nacionais e estrangeiros. Verifica-se que os programas que autorizam o abate nascem sob a justificativa do combate ao tráfico, mas se ligam às necessidades militares específicas de Peru e Colômbia. A lei brasileira surge para combater o transporte aéreo ilícito vinculado ao tráfico; contudo, sua origem e os debates posteriores para sua regulamentação submetem-se ao condicionamento dos temores e projetos militares em torno da defesa da soberania sobre a Amazônia brasileira.

Palavras-chave: defesa nacional; guerra às drogas; Lei do Abate; tráfico de drogas.

\section{Abstract}

This article analyze the creation and regulation of the Brazilian "Lei do Abate" that allow the shoot-down of civil aircraft suspected of involvement in drug trafficking. It investigated the relationship between the development of the Brazilian "Lei do Abate", the War on Drugs policy propagated by the U.S. government and the military strategic concerns about the security of the Amazon region. The research involved the study of the origins and transformations of the U.S. anti-drug policy since the 1960s and the War on Drugs model as part of the context of the creation of air bridge denial programs. We also examined the parliamentary debate to approve the bill proposed by the Executive Branch and the debates for their regulation. The research was carried out through the analysis of documents produced by the U.S. (open and confidential ones that were reclassified) and Brazil, through research in the annals of the Brazilian National Congress and through the study of Brazilian and international books and scientific articles. The programs that allows shoot-down of civil aircraft on flight was created under the excuse of combating trafficking, but are linked to specific military needs of Peru and Colombia. The Brazilian shoot-down program had been created to combat the illicit air transport linked to drug trafficking, but has close connections with the military projects for defending the sovereignty over the Brazilian Amazon.

Keywords: national security; War on Drugs; Lei do Abate; drug traffic. 